\title{
The effect of stress-induced cortisol increase on the sense of ankle proprioception
}

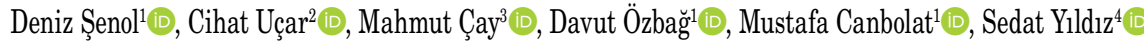 \\ 1Department of Anatomy, İnönü University Faculty of Medicine, Malatya, Turkey \\ ${ }^{2}$ Department of Physiology, Adiyaman University Faculty of Medicine, Adiyaman, Turkey \\ ${ }^{3}$ Department of Anatomy, Ussak University Faculty of Medicine, Uşak, Turkey \\ ${ }^{4}$ Department of Physiology, İnönü University Faculty of Medicine, Malatya, Turkey
}

Received: December 16, 2017 Accepted: July 05, 2018 Published online: August 15, 2018

\begin{abstract}
Objectives: The aim of this study is to analyze the effect of stress-induced cortisol increase on the sense of ankle proprioception.

Patients and methods: Between April 2016 and May 2016, a total of 60 students (30 males, 30 females; mean age: $19.2 \pm 1.5$ years; range, 19 to 20 years) from İnönü University, Faculty of Medicine, Department of Freshmen were included in the study. Separate measurements were made for the right and left ankle to make ankle proprioception measurements a month before the committee exam during their relaxed period using a device designed with digital inclinometer. The sense of ankle proprioception was measured at $10^{\circ}$ dorsiflexion (DF), $11^{\circ}$ plantar flexion (PF), and $25^{\circ} \mathrm{PF}$ angles with open eyes and closed eyes using active reproduction test. Salivary samples were taken for stress assessment and State Trait Anxiety Inventory-I (STAI-I) was conducted. The same tests were repeated on the day of committee exam. Results: Test results showed no statistically significant difference between the right and left ankle proprioception measurements of $10^{\circ} \mathrm{DF}$, $11^{\circ} \mathrm{PF}$, and $25^{\circ} \mathrm{PF}$ angles with open eyes ( $\left.\mathrm{p}>0.05\right)$. However, a statistically significant difference was found between the right and left ankle proprioception scores at the same angles with closed eyes $(\mathrm{p}<0.05)$. According to the Wilcoxon analysis conducted for the comparison of the relaxed and stressed periods of cortisol and STAI-I inventory, a statistically significant difference was found $(\mathrm{p}<0.05)$. The Spearman's Rho analysis showed no significant correlation between the right and left ankle proprioception scores and cortisol and STAI-I with open eyes, while there was a statistically significantly positive direction and low correlation between the same angles with closed eyes.
\end{abstract}

Conclusion: Our study results show that the increase in the stress-related cortisol is negative for the ankle proprioception sense.

Keywords: Cortisol; proprioception; stress.

Several studies investigating the association between stress and immune system have shown that two stress-sensitive endocrine response systems are hypothalamic-pituitary-adrenal (HPA) axis and sympathetic-medullary system (SAM). ${ }^{[1]}$ When an individual is faced with a stress-inducing condition, $s /$ he cannot control with existing coping mechanisms, HPA axis is activated through associative cortex, amygdala and hippocampus, respectively and due to the cortisol level in the blood rises and brain functions are affected through brain neurons and glucocorticoid receptors in glia cells. ${ }^{[2]}$ Cortisol is a steroidal hormone, it is released from the outer part of adrenal cortex, and it has glucocorticoid effect. ${ }^{[3,4]}$ Due to its small effect (MW $\sim 362 \mathrm{Da}$ ) and being soluble in fat, it transfers from capillary vessels to cells primarily through passive diffusion ${ }^{[4,5]}$ and diffuses to body parts such as saliva, cerebrospinal fluid, sweat, hair, and urine. ${ }^{[6]}$

During static and dynamic activities, our body should be able to perceive position, maintain balance, and move body parts in an order suitable for the purpose and in harmony. Our body should be aware of its position in the space on a conscious and unconscious level and be aware of its movements. ${ }^{[7]}$ Position perception of the body part which occurs 
due to the blending of ligaments around muscles, tendons, joint capsules and joints, afferent impulses from the skin and impulses from balance and vision system is called proprioception. ${ }^{[8]}$ Walking, running, writing, jumping up, throwing an object to the target and showing the agility to change the direction of the action suddenly can be done through proprioception. ${ }^{[9]}$

Proprioception is of utmost importance in, particularly, maintaining and continuing joint stability. ${ }^{[10,11]}$ During a movement, the structures in and around the joint are stretched and forced mechanically. As a result of this, the stimulated receptors help the movement and position to be perceived consciously through the afferent information they send to central nervous system. The motor activation required by the perceived body position is realized in an appropriately coordinated way thanks to the proprioceptive information. ${ }^{[12]}$ Insufficient functioning of proprioceptive system may lead to insufficient neuromuscular control, not being able to perform protective muscle activities and deterioration in the joint stabilization. ${ }^{[13]}$ Thus, the joint becomes defenseless against traumatic stimulants from the outside. Recurrent traumatic processes in the joint structures impair the structures of the mechanoreceptors, and this vicious cycle would damage proprioception more and more. ${ }^{[1]}$

Some of the physical reactions against stress are shaking, muscle spasm, myotonia, cramps, and numbness in fingers and toes. ${ }^{[14-18]}$ During stress, frequent physical symptoms and complaints are pain, strain, spasm, and arthralgia in the neck, back of the neck, waist and back; imbalance and swinging while standing, sitting and walking. ${ }^{[19]}$ In a study on cyclists, Filho et al. ${ }^{[20]}$ reported that stress factors changed in a short period of time and this change affected performance. In another study, Bali ${ }^{[21]}$ found that sportive performance was not only a biomechanical and physiological case, but it also affected performance severely and more than optimum stress would adversely affected stress. In general, proprioception is defined as the movement of the limbs and sense of position which arises through activity in sensory neurons inside the skin, muscles, and joint tissues. ${ }^{[22]}$

For a movement to take place most effectively, all systems contributing to the movement should work in coordination. Coordination is defined as the cooperative interaction of the nervous system and skeletal muscles and it includes proprioceptive senses. ${ }^{[23]}$ The primary situations in which coordination must function most intensively and perfectly are operational activities of security forces, sportive activities performed in front of ten thousands of audiences and surgical operations. In such cases when a smallest mistake can cause undesired results, the necessity of a perfect proprioceptive sense is indisputable. However, a common characteristic of these cases is the high level of stress they induce.

There are several studies in the literature on the effects of warming and stretching exercises, traumatic processes, surgical interventions, and warm-cold applications on proprioception. ${ }^{[24-26]}$ There are also special tools developed for the measurement of kinesthesia and the sense of joint position in proprioception measurement. Isokinetic dynamometers, goniometers, and inclinometers are some of these. ${ }^{[27]}$

The stress state of the patient should be taken into account in the measurement of proprioception and balance performed in physical therapy centers. Stress measurement should be done before and after the test. In the present study, we aimed to investigate the association between stress and proprioception which has not been studied before.

\section{PATIENTS AND METHODS}

Between April 2016 and May 2016, a total of 60 students ( 30 males, 30 females; mean age $19.2 \pm 1.5$ years; range, 19 to 20 years) from İnönü University, Faculty of Medicine, Department of Freshmen were included in the study. The inclusion criteria were being physically healthy, absence of any medical hindrance to participate in the study, absence of any disease, absence of orthopedic surgeries in the past, absence of resistance exercise at least six months before the start of the study, and absence of food supplement use, such as keratin during the study. The exclusion criteria were using antidepressant drugs and using herbal relaxants before the stressed and relaxed periods of the study. Female students who were in their menstruation phase or who would enter this phase within three days were also not included in the study. ${ }^{[28]}$ All participants were informed about the study and an informed consent form was obtained from each one. The study protocol was approved by the Malatya Clinical Researches Ethical Board (2016/137). The study was conducted in accordance with the principles of the Declaration of Helsinki.

First proprioception measurements and saliva samples were taken 30 days before the committee exam and this period was accepted as the relaxed period. Proprioception measurements and saliva samples of 
the same students were taken again on the day of the committee exam. This period was accepted as the stressed period. This period was considered stressed, as we thought that the stress of the students before the test would be high. We supported this hypothesis with the State Trait Anxiety Inventory-I (STAI-I) and cortisol measurements. There was a 30-day period between the relax period and the stressed period. The STAI-I was given to all students during the relaxed and stressed periods. The STAI-I is one of the common scales to assess anxiety. ${ }^{[29]}$ The validity and reliability studies of the Turkish version of the STAI-I were performed by Öner and Le Compte. ${ }^{[30]}$

According to the STAI-I, $\leq 36$ points are classified as "no anxiety", $37-42$ points as "mild anxiety", and $\geq 42$ points as "high anxiety". While the measurements were taken, the participants were in the sitting position with their legs extending in a quiet setting with normal room temperature. Baseline digital inclinometer (Model: 12-1057, Fabrication Enterprises, Inc., White Plains, New York, USA) was used to take the measurements. Proprioception is the measurement of the position sense. Separate measurements were taken for the right and left ankle to evaluate proprioception. Ankle proprioception was assessed in eyes open and eyes closed (EO, EC) position at $10^{\circ}$ dorsiflexion (DF), $11^{\circ}$ plantar flexion (PF), and $25^{\circ} \mathrm{PF}$ positions using active reproduction test. Joint position sense was assessed as repeating positioning actively and passively. First, the extremity on which the inclinometer was fastened was brought to the targeted angle and the subject was kept here for min $10 \mathrm{sec}$ to remember this position. Next, the extremity was taken to the initial position. The participant was asked to bring the extremity to the target angle again actively or to indicate when s/he reached the predetermined angle passively. Deviation from the targeted angle (angular error) was recorded. While active positioning (the ability to bring the extremity actively to the predetermined angle) measures the ability of muscular and capsular receptors, passive positioning primarily measures the ability of capsular receptors. ${ }^{[31,32]}$ The proprioceptive function was evaluated as a whole in this study. The method we used in this study is in line with the literature. ${ }^{[33]}$ Following a trial test, the participants were asked to move their ankles to target angles for three times and the mean values were obtained. The measured mean distance was recorded. The proprioception measurements were made by the medical doctor. All of the evaluation methods were applied to both the right and left sides. ${ }^{[33]}$

\section{Analysis of cortisol in saliva}

Passive droll method was used to collect the saliva samples as indicated by Granger et al. ${ }^{[34]}$ The samples were kept in a laboratory freezer at $-20^{\circ} \mathrm{C}$. The samples were centrifuged at $4000 \mathrm{~g}$ for $10 \mathrm{~min}$ following thawing, and the supernatant was used for the enzymelinked immunosorbent assay (ELISA) analyses. Using the assay buffer, all samples were diluted at 1:5 and assayed in triplicate. Using the ELISA procedure, cortisol-bovine serum albumin (BSA) stock solution $(1 \mathrm{mg} / \mathrm{mL})$ was diluted with carbonate buffer, $\mathrm{pH}$ 9.6, and added to a 96 -well microtiter plate at $200 \mu \mathrm{L} /$ well. The microtiter plate was incubated at $+4^{\circ} \mathrm{C}$ for one night and it was washed with washing buffer using eight-channel pipette for five times. Some of the binding places which did not have coating antigen were blocked at $37^{\circ} \mathrm{C}$ for two hours using the blocking buffer $(200 \mu \mathrm{L} /$ well). After washing, standard solutions or samples $(40 \mu \mathrm{L} /$ well) and diluted first $\mathrm{Ab}$ (antiserum) (40 $\mu \mathrm{L} /$ well) were put in duplicate and incubated for $45 \mathrm{~min}$ at $37^{\circ} \mathrm{C}$. Biotinylated anti-rabbit antibody was added $(100 \mu \mathrm{L} /$ well $)$ following the washing process, and the plate was incubated for $30 \mathrm{~min}$ at $37^{\circ} \mathrm{C}$. Streptavidin peroxidase solution $(100 \mu \mathrm{L} /$ well $)$ was added after washing for five times, and the plate was incubated at $+4^{\circ} \mathrm{C}$ for $15 \mathrm{~min}$. Then, substrate solution $(150 \mu \mathrm{L} /$ well) was added, after the plate was washed for another five times and it was incubated for $10 \mathrm{~min}$ in dark. Stop solution (50 $\mu \mathrm{L} /$ well) was also added after incubation, and using the microplate reader, the absorbance was measured at $450 \mathrm{~nm}$. Inter-assay variation was found to be $7.8 \%$, while the inter-assay coefficients of variation (CV) were found to be $5.6 \%$. The ELISA test was conducted by a single laboratory and a single expert. ${ }^{[28]}$

\section{Statistical analysis}

Statistical analysis was performed using the IBM SPSS version 22.0 software (IBM Corp., Armonk, NY, USA). Descriptive data were expressed in median (min-max). The Kolmogorov-Smirnov test was used to analyze whether the data were normally distributed. The Wilcoxon paired-samples test was used to analyze the data which were not normally distributed. Correlations were calculated using the Spearman Rho coefficient. The limits of the correlation coefficient were assumed to be between -1 and +1 . While the correlation coefficient whose magnitude between 0.5 to 1.0 indicate variables considered to be highly correlated, those between 0.3 to 0.5 are moderately correlated and those between 0 to 0.3 have a low correlation. ${ }^{[35]}$ For the sample size, 95\% confidence 
Table 1. Values of cortisol and STAI-I and correlation analysis results between cortisol level and STAI-I in exam period

\begin{tabular}{|c|c|c|c|c|c|c|c|}
\hline \multirow[b]{2}{*}{ Variables } & \multicolumn{2}{|c|}{ Relaxed } & \multicolumn{2}{|c|}{ Stressed } & \multirow[b]{2}{*}{$p$} & \multicolumn{2}{|c|}{ Exam period } \\
\hline & Median & Min-Max & Median & Min-Max & & Correlation & Cortisol \\
\hline Cortisol & 18.4 & $4.6-116.8$ & 47.5 & $2.9-1028.2$ & $<0.001$ & STAI-I & $\mathrm{r}=0.245$ \\
\hline STAI-I & 37.4 & $20-56$ & 53.4 & $30-75$ & $<0.001$ & & $\mathrm{p}=0.005$ \\
\hline
\end{tabular}

STAI-I: State Trait Anxiety Inventory-I; Min: Minimum; Max: Maximum.

interval (CI) in the G-Power 3.1.7 package program (Heinrich-Heine-Universität, Dusseldorf, Germany) was calculated for the paired samples t-test at the beginning of the study. The minimum sample size for alpha $=0.05$ and 1-beta $=0.80$ was calculated as 52 , when the effect size was estimated to be 0.40 to determine at least $1^{\circ}$ of angular change in the sense of ankle proprioception. The Cronbach's alpha value was calculated to evaluate reliability. The reliability of the scale is accepted as good, if the coefficient is $\geq 0.70 .^{[36]}$ As a result of analysis, Cronbach's alpha value was 0.701 indicating that our measurements were very reliable in our study. The Cronbach's alpha coefficient is accepted as a coefficient used to determine the reliability of almost all repeated measurements and testing instruments. ${ }^{[36]}$ A $p$ value of $<0.05$ was considered statistically significant.

\section{RESULTS}

The median value of cortisol levels in saliva samples increased approximately 2.5 times in the relaxed period compared to the stressed period. The STAI-I scores also increased. The Wilcoxon paired-samples test was conducted on the data to find out whether the increases in cortisol and STAI-I scores in relaxed and stressed period were significant. According to the analysis results, a statistically significant increase was found in the relaxed and stressed period cortisol and STAI-I scores $(\mathrm{p}<0.05)$ (Table 1). As a result of the Spearman rho correlation analysis of the STAI-I and cortisol levels during the examination period, it was found that there was a positive direction and low correlation between the cortisol and STAI-I data during the examination period $(\mathrm{r}=0.245, \mathrm{p}<0.05)$ (Table 1).

Statistically significant median values were determined in closed eyes measurements in the right and left ankle proprioception measurements. Relaxed period measurement was found to be $2.5^{\circ}$ and stressed period measurement was found to be $4.6^{\circ}$ at $\mathrm{EC} 10^{\circ} \mathrm{DF}$; relaxed period measurement was found to be $1.9^{\circ}$ and stressed period measurement was found to be $3.2^{\circ}$ at $\mathrm{EC} 11^{\circ} \mathrm{PF}$; relaxed period measurement was found to be $3^{\circ}$ and stressed period measurement was found to be $5.9^{\circ}$ at $\mathrm{EC} 25^{\circ} \mathrm{PF}$ in the right ankle. Relaxed period measurement was found to be $2.6^{\circ}$ and stressed period measurement was found to be $3.7^{\circ}$ at $\mathrm{EC} 10^{\circ} \mathrm{DF}$; relaxed period measurement was found to be $1.7^{\circ}$ and stressed period measurement was found to be $3.3^{\circ}$ at $\mathrm{EC} 11^{\circ} \mathrm{PF}$; relaxed period measurement was found to be $3.1^{\circ}$ and stressed period measurement was found to be $5.6^{\circ}$ at $\mathrm{EC} 25^{\circ} \mathrm{PF}$ in the left ankle (Table 2).

The Spearman's rho correlation analysis results conducted on the differences between the relaxed and stressed period proprioception scores are given in Table 3. It was found that cortisol which increased with stress had a negative influence on the proprioception scores. The results of correlation analysis conducted

Table 2. Values and test results of proprioception measurements

\begin{tabular}{|c|c|c|c|c|c|c|c|c|c|c|}
\hline \multirow[b]{3}{*}{ Variables } & \multicolumn{4}{|c|}{ Right ankle } & \multirow[b]{3}{*}{$p$} & \multicolumn{4}{|c|}{ Left ankle } & \multirow[b]{3}{*}{$p$} \\
\hline & \multicolumn{2}{|c|}{ Relaxed } & \multicolumn{2}{|c|}{ Stressed } & & \multicolumn{2}{|c|}{ Relaxed } & \multicolumn{2}{|c|}{ Stressed } & \\
\hline & Median & Min-Max & Median & Min-Max & & Median & Min-Max & Median & Min-Max & \\
\hline $\mathrm{EO} 10^{\circ} \mathrm{DF}$ & 1.9 & $0-5.6$ & 1.3 & $0-5.2$ & 0.101 & 1.7 & $0-6.3$ & 1.3 & $0-7.2$ & 0.095 \\
\hline $\mathrm{EO}^{\circ} 1^{\circ} \mathrm{PF}$ & 2 & $0-12.6$ & 1.9 & $0.1-7.4$ & 0.426 & 2 & $0-9$ & 1.9 & $0.1-8.2$ & 0.444 \\
\hline $\mathrm{EO} 25^{\circ} \mathrm{PF}$ & 1.9 & $0-11.4$ & 3.1 & $0-9.4$ & 0.139 & 2.5 & $0-11.8$ & 2.1 & $0.1-10.8$ & 0.143 \\
\hline $\mathrm{EC} 10^{\circ} \mathrm{DF}$ & 2.5 & $0-6.6$ & 4.6 & $0.8-12.5$ & $<0.001$ & 2.6 & $0-7.6$ & 3.7 & $0.1-11.3$ & $<0.001$ \\
\hline $\mathrm{EC} 11^{\circ} \mathrm{PF}$ & 1.9 & $0.1-8.2$ & 3.2 & $0.3-12.5$ & $<0.001$ & 1.9 & $0.1-8.3$ & 3.3 & $0.4-9.5$ & $<0.001$ \\
\hline $\mathrm{EC} 25^{\circ} \mathrm{PF}$ & 3 & $0-9.5$ & 5.9 & $1.4-13.7$ & $<0.001$ & 3.1 & $0-7.8$ & 5.6 & $1.1-13.6$ & $<0.001$ \\
\hline
\end{tabular}

Min: Minimum; Max: Maximum; EO: Eyes open; EC: Eyes closed; DF: Dorsiflexion; PF: plantar flexion. 
Table 3. Correlation analysis results conducted on the proprioception scores

\begin{tabular}{|c|c|c|c|c|c|}
\hline \multirow[b]{2}{*}{ Variables } & \multirow[b]{2}{*}{ Test statistics } & \multicolumn{2}{|c|}{ Right ankle } & \multicolumn{2}{|c|}{ Left ankle } \\
\hline & & Cortisol & STAI-I & Cortisol & STAI-I \\
\hline \multirow{2}{*}{$\mathrm{EO} 10^{\circ} \mathrm{DF}$} & $\mathrm{r}$ & 0.102 & 0.104 & 0.096 & 0.012 \\
\hline & $\mathrm{p}$ & 0.270 & 0.256 & 0.297 & 0.898 \\
\hline \multirow{2}{*}{$\mathrm{EO}^{\circ} 1^{\circ} \mathrm{PF}$} & $\mathrm{r}$ & 0.041 & 0.078 & 0.127 & 0.003 \\
\hline & $\mathrm{p}$ & 0.654 & 0.399 & 0.167 & 0.973 \\
\hline \multirow{2}{*}{$\mathrm{EO} 25^{\circ} \mathrm{PF}$} & $\mathrm{r}$ & 0.115 & 0.122 & 0.001 & 0.144 \\
\hline & $\mathrm{p}$ & 0.210 & 0.184 & 0.994 & 0.117 \\
\hline \multirow{2}{*}{$\mathrm{EC} 10^{\circ} \mathrm{DF}$} & $\mathrm{r}$ & 0.293 & 0.387 & 0.172 & 0.215 \\
\hline & $\mathrm{p}$ & 0.001 & 0.036 & 0.041 & 0.018 \\
\hline \multirow{2}{*}{$\mathrm{EC} 11^{\circ} \mathrm{PF}$} & $\mathrm{r}$ & 0.191 & 0.169 & 0.238 & 0.197 \\
\hline & $\mathrm{p}$ & 0.036 & 0.045 & 0.009 & 0.031 \\
\hline \multirow{2}{*}{$\mathrm{EC} 25^{\circ} \mathrm{PF}$} & $\mathrm{r}$ & 0.188 & 0.235 & 0.113 & 0.183 \\
\hline & $\mathrm{p}$ & 0.040 & 0.010 & 0.218 & 0.46 \\
\hline
\end{tabular}

STAI-I: State Trait Anxiety Inventory-I; EO: Eyes open; EC: Eyes closed; DF: Dorsiflexion; PF: plantar flexion..

Table 4. Change of individual numbers according to STAI-I score

\begin{tabular}{lcccccc}
\hline & $<36$ (no anxiety) & \multicolumn{2}{c}{$37-42$ (mild anxiety) } & \multicolumn{2}{c}{$>$ (high anxiety) } \\
\hline Period & $\mathrm{n}$ & $\%$ & $\mathrm{n}$ & $\%$ & $\mathrm{n}$ & $\%$ \\
Relaxed & 29 & 48.3 & 13 & 21.7 & 18 & 30 \\
Stressed & 3 & 5 & 6 & 10 & 51 & 85 \\
\hline
\end{tabular}

STAI-I: State Trait Anxiety Inventory-I.

with the STAI-I also supported this result (r-correlation coefficient; between 0 and $1, \mathrm{p}<0.05$ ) (Table 3).

According to the STAI-I scores in the relaxed and stressed periods, the number of anxious and mildly anxious individuals decreased in the stressed period compared to the relaxed turnover, although a high increase in the number of the highly anxious individuals was found according to the variation of the anxious individuals (Table 4).

\section{DISCUSSION}

As a result of our study, the level of cortisol and STAI-I anxiety scores increased in the stressed period compared to the relaxation period. In addition, it was found that there was a positive direction and low correlation between the cortisol analysis results and STAI-I scores in the stressed period. We also showed that there was a change in the right and left ankle proprioception measurements at $10^{\circ} \mathrm{DF}$, $11^{\circ} \mathrm{PF}$, and $25^{\circ} \mathrm{PF}$ with eyes closed, while there was a positive direction and low and moderate correlation between these angular changes and cortisol and STAI-I scores. Stress was found to have an adverse effect on the sense of proprioception. To the best of our knowledge, this is the first study in the literature. When the previous studies are examined, it seems to be quite unique. It is, therefore, difficult to discuss the results we achieved.

Individuals who are faced with the effects of a stress inducer respond by a physiological or psychological defense. ${ }^{[37]}$ It has been reported that compared to relaxed individuals, stressed individuals may easily make mistakes, are more anxious, and uneasy. ${ }^{[38]}$

Balance and keeping a stable posture is an indispensable part of most movement practices. ${ }^{[39]}$ In addition to the integration of sensory inputs, balance control is a complex motor ability which includes planning and applying flexible move patterns. ${ }^{[40]}$

As a response to stress, endocrine system starts to release cortisol and sudden increase of cortisol is an adaptive function. ${ }^{[41]}$ In stabilizing the joints, proprioceptive mechanisms seem to have a role between static stabilizers and dynamic muscular restraints, and they may function as a means for interplay. ${ }^{[42]}$

In our daily lives, the position and proprioception of the lower extremity and, thus, the ankle, become important while standing and walking and creating and maintaining balance. In a study including 35 medical faculty students, Singh et al. ${ }^{[43]}$ measured the cortisol levels of students in relaxed and stressed 
periods to find out exam stress. They found the level of cortisol in male students to be $2.48 \pm 1.5 \mathrm{ng} / \mathrm{mL}$ and in female students to be $2.92 \pm 1.9 \mathrm{ng} / \mathrm{mL}$ in relaxed period; while they found the level of cortisol in male students to be $5.02 \pm 3.1 \mathrm{ng} / \mathrm{mL}$ and in female students to be $5.19 \pm 3.1 \mathrm{ng} / \mathrm{mL}$ in stressed period. In their study, Schoofs et al. ${ }^{[44]}$ found that academic exams increased saliva cortisol in very high levels.

Muammer et al. ${ }^{[45]}$ reported that there were no differences between pre- and post-training proprioception measurements of women with a mean age of $22.47 \pm 1.12$ years who were receiving yoga training. As a result of the proprioception tests conducted on the ankles of gymnasts and control group in their study, Aydın et al. ${ }^{[42]}$ found that gymnastic training had a positive effect on proprioception and balance tests and increasing muscle tonus. Muammer et al. ${ }^{[33]}$ also conducted proprioception assessment on 30 athletes and 30 sedentary in EO and EC position. They found that proprioception test results were higher in athletes compared to the sedentary participants. In addition, Pánics et al. $^{[46]}$ found that the proprioception in female handball players increased at the end of the season compared to the season before the start of the season.

In the present study, we found statistically significant deviations in both dorsal flexion and plantar flexion values in both ankles in eyes closed position compared to the EO position. We believe that this finding is significant, since in stressed moments, the error rate would increase in critical decisions or actions. It can be seen as an undeniable fact that security staff, surgeons, athletes, or artists who perform in front of millions of individuals need a stress-free environment so that they can show maximum efficiency and minimum mistakes. It is inevitable that there would be stress resulting from the nature of the task or the performance. However, a stress-free life should be provided in the professional life of individuals who have such critical jobs. Their psychological conditions should be recorded periodically and these assessments should be taken into consideration while assigning them with duties.

There are some limitations to this study. First, the sample size is small. However, since the time per measurement was too long and the time available for completing the measurements was too short, we included the required number of participants in accordance with the power analysis. Second, in the days following the stressful period, no measurement was able to be performed. We, therefore, recommend further studies investigating changes in the cortisol levels over time.

In conclusion, our study results shows that stress adversely affects the sense of proprioception. The study should also be considered for the measurements made at physical therapy centers. Proprioception and equilibrium measurements can reveal unfavorable outcomes due to stress. We believe that this study which analyzes the association between stress and proprioceptive sense, which has not been studied before, would be a source of significant changes in institutional and individual life.

\section{Declaration of conflicting interests}

The authors declared no conflicts of interest with respect to the authorship and/or publication of this article.

\section{Funding}

The authors received no financial support for the research and/or authorship of this article.

\section{REFERENCES}

1. Cohen S, Janicki-Deverts D, Miller GE. Psychological stress and disease. JAMA 2007;298:1685-7.

2. Huether G, Doering S, Ruger U, Ruther E, Schussler G. The stress-reaction process and the adaptive modification and reorganization of neuronal networks. Psychiatry Research 1999;87:83-95.

3. Kirschbaum C, Hellhammer DH. Salivary cortisol. Encyclopedia Stress 2000;3:379-83.

4. Gatti R, Antonelli G, Prearo M, Spinella P, Cappellin E, De Palo EF. Cortisol assays and diagnostic laboratory procedures in human biological fluids. Clin Biochem 2009; 42:1205-17.

5. Levine A, Zagoory-Sharon O, Feldman R, Lewis JG, Weller A. Measuring cortisol in human psychobiological studies. Physiology Behavior 2007;90:43-53.

6. Kaushik A, Vasudev A, Arya SK, Pasha SK, Bhansali S. Recent advances in cortisol sensing technologies for point-of-care application. Biosens Bioelectron 2014;53:499-512.

7. Gillquist J. Knee ligaments and proprioception. Acta Orthop Scand 1996;67:533-5.

8. Safran MR, Allen AA, Lephart SM, Borsa PA, Fu FH, Harner CD. Proprioception in the posterior cruciate ligament deficient knee. Knee Surg Sports Traumatol Arthrosc 1999;7:310-7.

9. Houglum PA. The ABCs of the proprioception. In: Houglum PA, editor. Therapeutic exercise for musculoskeletal injuries. 2nd ed. Chapter 8. Champaign, IL: Human Kinetics; 2005. p. 259-75.

10. Pai YC, Rymer WZ, Chang RW, Sharma L. Effect of age and osteoarthritis on knee proprioception. Arthritis Rheum 1997;40:2260-5. 
11. Sharma L. Proprioceptive impairment in knee osteoarthritis. Rheum Dis Clin North Am 1999;25:299-314.

12. Sharma L, Pai YC. Impaired proprioception and osteoarthritis. Curr Opin Rheumatol 1997;9:253-8.

13. Irrgang JJ, Neri R. The Rationale for open and closed kinetic chain activities for restoration of proprioception and neuromuscular control following injury. In: Lephard $\mathrm{SM}, \mathrm{Fu} \mathrm{FH}$, editors. Proprioception and neuromuscular control in joint stability. 1st ed. Pittsburg: Human Kinetics; 2000. p. 363-72.

14. Güçlü N. Stres yönetimi. G.Ü. Gazi Eğitim Fakültesi Dergisi 2001;21:91-109.

15. James J, Edden M. Uzun Saplı Gelincik. İstanbul: MESS Yayınlar1;2001.

16. Aytaç S, Bayram N. Marmara Depremi Sonrası Bireylerdeki Stres Tepkilerinin Analizi. Dokuz Eylül Üniversitesi Sosyal Bilimler Enstitüsü Dergisi 2000;2:42-61.

17. Markham U. Kadınlar için Stres El Kitabı. İstanbul: Alfa Yayınları:1998.

18. Arsenault A, Dolan S. The role of personality, occupation and organization in understanting the relationship between job stress, performance and absenteeism. Journal of Occupational Psychology 1983;56:227-40.

19. Morgan G. İşte ve Yasamda Stres'i Yenmenin Yolları. İstanbul: Ruh Bilim Yayınları; 1996. s. 103.

20. Filho E, di Fronso S, Forzini F, Murgia M, Agostini T, Bortoli $\mathrm{L}$, et al. Athletic performance and recovery-stress factors in cycling: An ever changing balance. Eur J Sport Sci 2015;15:671-80.

21. Bali A. Psychological factors affecting sports performance. IJPESH 2015;1:92-5.

22. Grigg P. Peripheral neural mechanisms in proprioception. Journal of Sport Rehabilitation 1994;3:2-17.

23. Tittel K. Coordination and balance. In: Encyclopedia of Sports Medicine. In: Dirix A, Knuttgen HG, Tittel K, editors. Vol 1. Oxford: Blackwell Scientific Pub; 1988. p. 194-211.

24. Funk DC, Swank AM, Mikla BM, Fagan TA, Farr BK. Impact of prior exercise on hamstring flexibility: a comparison of proprioceptive neuromuscular facilitation and static stretching. J Strength Cond Res 2003;17:489-92.

25. Yildırım MS, Ozyurek S, Tosun O, Uzer S, Gelecek N. Comparison of effects of static, proprioceptive neuromuscular facilitation and Mulligan stretching on hip flexion range of motion: a randomized controlled trial. Biol Sport 2016;33:89-94.

26. Burke DG, Holt LE, Rasmussen R, MacKinnon NC, Vossen JF, Pelham TW. Effects of Hot or Cold Water Immersion and Modified Proprioceptive Neuromuscular Facilitation Flexibility Exercise on Hamstring Length. J Athl Train 2001;36:16-19.

27. Ergen E, Ulkar B. Proprioception and Coordination. çinde Pioli S, editör. Clinical Sports Medicine. New York: Sounders Elsevier; 2007. p. 237-55.

28. Ozgocer T, Ucar C, Yildiz S. Cortisol awakening response is blunted and pain perception is increased during menses in cyclic women. Psychoneuroendocrinology 2017;77:158-64.
29. Fernández-Blázquez MA, Ávila-Villanueva M, López-Pina JA, Zea-Sevilla MA, Frades-Payo BPsychometric properties of a new short version of the State-Trait Anxiety Inventory (STAI) for the assessment of anxiety in the elderly. Neurologia 2015;30:352-8.

30. Öner N, Le A. Compte. Durumluk-Sürekli Kaygı Envanteri El Kitabı. İstanbul: Boğaziçi Üniversitesi Yayını; 1983.

31. Beynnon BD, Good L, Risberg MA. The effect of bracing on proprioception of knees with anterior cruciate ligament injury. J Orthop Sports Phys Ther 2002;32:11-5.

32. Voight M, Blackburn T. Proprioception and Balance Training and Testing Fallowing Injury. In: Allen A, editor. Knee Ligament Rehabilitation. New York: Chuchill Livingstone; 2000. p. 361-85.

33. Muammer R, Cımbız A, İnal S. Relationship between skin resistance level, ankle joint proprioception and balance of the athletes. International Journal of Sport Studies 2015;5:129-35.

34. Granger DA, Kivlighan KT, el-Sheikh M, Gordis EB, Stroud LR. Salivary alpha-amylase in biobehavioral research: recent developments and applications. Ann N Y Acad Sci 2007;1098:122-44.

35. Cohen J. Statistical power analysis for the behavioral sciences. 2nd ed. New York: Lawrence Erlbaum Associates; 1988.

36. Kula Kartal S, Mor Dirlik E. Geçerlik kavramının tarihsel gelişimi ve güvenirlikte en çok tercih edilen yöntem: Cronbach Alfa Katsayısı. Abant İzzet Baysal Üniversitesi Eğitim Fakültesi Dergisi 2016;16:1865-79.

37. Sanlı T. Hemşirelikte Kişilerarası İlişkileri Etkileyen Temel Kavramlar. In: Geylan R, editör. Hemşirelikte Kişilerarası İlişkiler. Ankara: Açıkögretim Fakültesi Yayınları; 1993. s. 48-84.

38. Makin PE, Lindley PA. Pozitif Stres Yönetimi. İstanbul: Rota Yayın Yapım Tanıtım Ticaret Ltd.Sti. Yayınları; 1995.

39. Carr JH, Shepherd R. Neurological Rehabilitation: Optimising Motor Performance. Oxford: ButterworthHeineman; 1998.

40. Ferdjallah M, Harris GF, Smith P, Wertsch JJ. Analysis of postural control synergies during quiet standing in healthy children and children with cerebral palsy. Clin Biomech (Bristol, Avon) 2002;17:203-10.

41. Hansen-Grant SM, Pariante CM, Kalin NH, Miller AH. Neuroendocrine and immune system pathology in psychiatric disease. In: Schatzberg AF, Nemeroff CB, editors. The American Psychiatric Press Textbook of Psychopharmacology: Washington DC: American Psychiatric Press; 1998. p. 171-94.

42. Aydin T, Yildiz Y, Yildiz C, Atesalp S, Kalyon TA. Proprioception of the ankle: a comparison between female teenaged gymnasts and controls. Foot Ankle Int 2002;23:123-9.

43. Singh R, Goyal M, Tiwari S, Ghildiyal A, Nattu SM, Das S. Effect of examination stress on mood, performance and cortisol levels in medical students. Indian J Physiol Pharmacol 2012;56:48-55.

44. Schoofs D, Hartmann R, Wolf OT. Neuroendocrine stress responses to an oral academic examination: No strong influence of sex, repeated participation and personality traits. Stress 2008;11:52-61. 
45. Muammer R, Calisgan S, Senol D. The effect of yoga training on balance and proprioception of ankle. International Journal of Sport Studies 2015;5:1079-82.
46. Pánics G, Tállay A, Pavlik A, Berkes I. Effect of proprioception training on knee joint position sense in female team handball players. Br J Sports Med 2008;42:472-6. 